\title{
Characterization of Type 2 Diabetes into Five Sub-Types
}

\author{
Susan J Appel ${ }^{1 *}$ and Theresa M Wadas ${ }^{2}$ \\ ${ }^{1}$ Professor, Capstone College of Nursing, The University of Alabama, USA \\ ${ }^{2}$ Assistant Professor, Capstone College of Nursing, The University of Alabama, USA
}

Submission: June 14, 2018; Published: July 24, 2018

*Corresponding author: Susan J Appel, Professor, Capstone College of Nursing, The University of Alabama, Box 870358, Tuscaloosa, AL 35487 0358, USA, Tel: 205-348-1026; Email: sjappel@ua.edu

Abstract

This mini-review discuss the findings of Ahlqvist et al. [1] recently published results in Lancet, showing that they could further characterize type 2 diabetes into five subtypes. Participants with type 2 diabetes were from Scandinavia. Common clinical measures were used to stratify by clusters (e.g., age of onset, body mass index, A1c, glutamate acid decarboxylase antibodies, homeostatic model assessment2-insulin resistance and beta cell function). Each of the five subtypes had unique but homogeneous presentations, alike responses to specific medications and developed similar complications by classification. This clinically useful classifications of type 2 diabetes management has been recognized as a major step toward precision medicine.

\section{Introduction}

Healthcare providers caring for patents living with type 2 diabetes have long noted heterogeneous characteristics of onset and progression of the disease state, all leading to a variety of complications. Interestingly, some patients diagnosed with type 2 diabetes would manifest the onset of their disease with sever hyperglycemia to the degree of constituting a diabetes emergency requiring hospitalization. This abrupt onset was often similar to those diagnosed with onset of type 1 diabetes. Whereas, among other patients, onset of the disease would occur more slowly. Likewise, the rate and types of complications seemed to vary greatly by patients suffering from the same diagnosis at various levels of body mass index (BMI). Managing these patients with certain oral hypoglycemic agents and timing for need to add insulin had wide-ranging responses. These observations have caused many providers to feel overwhelmed when attempting to manage this detrimental and varied disease process. In short, providers had rightly concluded that treating the individual living with diabetes must be personalized to optimize glycemic responses.

These same clinical observations led a group of researchers in Sweden at Lund University to attempt to more fully characterize type 2 diabetes. Recently, Ahlqvist et al. [1] published their study results in Lancet, showing that they could further characterize type 2 diabetes into five subtypes. Participants with type 2 diabetes were from Scandinavia. Each of the five subtypes had unique but homogeneous presentations, alike responses to specific medications and developed similar complications by classification. Gloyn \& Drucker [2] declare that this is a clinically useful classifications of type 2 diabetes management as it is a major step toward precision medicine.

\section{Discussion}

Overall the classification of type 2 diabetes into five distinct clusters or subtypes may be considered superior to that of types 1 or 2 alone. As when providers are able to identify subtypes this potentially allows targeting of patients who are at higher risk for specific complications. A brief overview of the five subtypes will be reviewed here and are summarized in Table 1.

The first two clusters seem to be closely aligned with type 1 diabetes and/or latent autoimmune diabetes in adults (LADA) $[3,4]$. These subtypes represent the more sever classifications of type 2 diabetes and present similar to type 1 diabetes.

\section{Cluster 1}

Severe Autoimmune Diabetes (SAID) has on early onset 20-30 years of age and may present with a diabetes emergency such as diabetes ketoacidosis (DKA). This is the only glutamate acid decarboxylase antibodies (GADA) positive subtype which is therefore a hallmark finding and related to HLA genetic locust $[5,6]$. Commonly, body mass index (BMI) is low to normal, insulin resistance is low as signified by lower homeostatic model assessment2-insulin resistance (HOMA2-ir) [7]. Likewise, low 


\section{Current Research in Diabetes \& Obesity Journal}

levels of homeostatic model assessment 2-beta cell function (HOMA2-b) and low levels of C-peptides indicating low levels of insulin production [8]. A1c levels are usually elevated at diagnosis and there is a short time until oral agents fail to maintain euglycemia and within a short time insulin must be added to optimize glycemic control. This sub-type classification is at high risk for development of diabetes related eye disease such as retinopathy. Therefore, early use of insulin therapy coupled with meticulous and frequent screening dilated eye exams are paramount.

Table 1: Adapted from: Ahlqvist et al. [1]. Koivula et al. [10].

\begin{tabular}{|c|c|c|c|c|c|c|c|c|c|c|}
\hline Cluster & Descriptive Name & $\begin{array}{l}\text { Age On } \\
\text { set }\end{array}$ & BMI & GADA & C-Peptides & HOMA2-IR & $\begin{array}{l}\text { HOMA2- } \\
\text { B }\end{array}$ & A1c & Medications & $\begin{array}{l}\text { Complications and } \\
\text { Pheno type }\end{array}$ \\
\hline $1: 00$ & $\begin{array}{c}\text { Severe Autoimmune } \\
\text { Diabetes (SAID)Severe } \\
\text { Autoimmune Diabetes } \\
\text { (SAID) }\end{array}$ & $\begin{array}{l}\text { Early } \\
20-35\end{array}$ & Low & + & Low & Low & Low & $\begin{array}{c}\text { Elevated } \\
\text { at } \\
\text { diagnosis }\end{array}$ & $\begin{array}{l}\text { Short time till } \\
\text { need to start } \\
\text { insulin }\end{array}$ & $\begin{array}{l}\text { DKA upon diagnosis } \\
\text { (Overlap with T1D \&/or } \\
\text { LADA). HLA genetic locus } \\
\text { Early diabetes related eye } \\
\text { disease and retinopathy }\end{array}$ \\
\hline 2 & $\begin{array}{l}\text { Severe Insulin-Deficient } \\
\text { Diabetes (SIDD) Severe } \\
\text { Insulin-Deficient } \\
\text { Diabetes (SIDD) (similar } \\
\text { to cluster } 1 \text {, but GADA } \\
\text { negative) }\end{array}$ & $\begin{array}{l}\text { Early to } \\
\text { Mid-life }\end{array}$ & $\begin{array}{l}\text { Low- } \\
\text { Moderate }\end{array}$ & - & Low & $\begin{array}{l}\text { Moderately- } \\
\text { Low }\end{array}$ & Low & $\begin{array}{l}\text { Elevated } \\
\text { at } \\
\text { diagnosis }\end{array}$ & $\begin{array}{l}\text { Short time } \\
\text { to second PO } \\
\text { Meds }\end{array}$ & $\begin{array}{l}\text { Possible DKA upon } \\
\text { diagnosis Poor response } \\
\text { to insulin. May take long } \\
\text { time to reach treatment } \\
\text { goal. Early and highest } \\
\text { occurrence of Retinopathy } \\
\text { Liver disease, chronic } \\
\text { kidney disease }\end{array}$ \\
\hline 3 & $\begin{array}{l}\text { Severe Insulin-Resistant } \\
\text { Diabetes (SIRD) Severe } \\
\text { Insulin-Resistant } \\
\text { Diabetes (SIRD) }\end{array}$ & $\begin{array}{l}\text { Latter } \\
60>\end{array}$ & Elevated & - & Moderate & High & High & Varies & $\begin{array}{l}\text { Optimize } \\
\text { Metformin } \\
\text { \& Consider } \\
\quad \text { renal } \\
\text { protective } \\
\text { meds }\end{array}$ & $\begin{array}{l}\text { Highly insulin resistance } \\
\text { highest occurrence of } \\
\text { nephropathy and NASH }\end{array}$ \\
\hline 4 & $\begin{array}{c}\text { Mild Obesity-related } \\
\text { Diabetes (MOD)Mild } \\
\text { Obesity-related Diabetes } \\
\text { (MOD) }\end{array}$ & $\begin{array}{l}\text { Mid-life } \\
45-55\end{array}$ & $\begin{array}{c}\text { Very } \\
\text { Elevated }\end{array}$ & - & Moderate & $\begin{array}{l}\text { Moderately- } \\
\text { Low }\end{array}$ & Moderate & Varies & $\begin{array}{l}\text { PO Meds } \\
\text { Consider Sq } \\
\text { GLP-1 }\end{array}$ & $\begin{array}{l}\text { Occurs at early age Obsess } \\
\text { but not insulin resistance }\end{array}$ \\
\hline 5 & $\begin{array}{c}\text { Mild Age-Related } \\
\text { Diabetes (MARD)Mild } \\
\text { Age-Related Diabetes } \\
\text { (MARD) }\end{array}$ & $\begin{array}{l}\text { Later } \\
65>\end{array}$ & $\begin{array}{l}\text { Low- } \\
\text { Moderate }\end{array}$ & - & Moderate & Low & Moderate & Varies & $\begin{array}{l}\text { PO Meds: } \\
\text { Metformin \& } \\
\text { Lifestyle }\end{array}$ & Presents among elderly. \\
\hline
\end{tabular}

\section{Cluster 2}

Severe Insulin-Deficient Diabetes (SIDD) is very similar to cluster 1, but is GADA negative, and may respond to oral agents but there may quickly be a need to add a second or third oral agents to obtain glycemic control. Poor response to insulin, manifested highest prevalence of retinopathy. As with cluster 1 , meticulous and frequent screening dilated eye exams are paramount.

\section{Cluster 3}

Severe Insulin Resistant Diabetes (SIRD): has a latter onset around 60, elevated BMI and manifest the highest level of insulin resistance as indicated by a higher HOMA2-ir. Therefore, use of metformin should be optimized. Close scrutiny for complications should focus on diabetes related eye, liver and kidney diseases. Use of renal protective medications such as an angiotensinconverting-enzyme inhibitor (ACEI) or angiotensin II Receptor Blockers (ARBs) is an imperative early intervention. Along with close monitoring of renal and liver function.

\section{Cluster 4}

Mild Obesity-related Diabetes (MOD): onset is mid-life with milder metabolic derangements. High level of BMI, but low insulin resistance. Consideration should be given to choosing weight neutral or those diabetes agent that facilitate weight loss.

\section{Cluster 5}

Mild Age-Related Diabetes (MARD): onset occurs later in life $>65$ years of age and BMI is low to moderately elevated. Focus of management should be focused heavily on lifestyle modifications and use of oral diabetes medications.

\section{Conclusion}

Although the clinical advantages of this newly proposed five sub-type classifications of type 2 diabetes can at this point only be theorized. Further characterization of type 2 diabetes potentially can be used to target patients who are at higher risk of specific diabetes related complications. As well as guide providers in the first line choices of therapy to more quickly gain glycemic control. Likewise, to focus office time and followup specialty visits on areas where the patients has the highest risk of early complications. Still considerable value can be found in the understanding the characteristics of a patient's subtype of diabetes. As this may allow providers to tailor education and to prepare the patient as to what to expect with outcomes of therapy. For example, in clusters 1 and 2 the patient needs to 
be educated that due to their specific sub-type they may require additional oral medications and/or insulin earlier versus later. The intensification of medication therapy should not be blamed on the patient's lack of diabetes self-management. Likewise, knowing the patients subtype may ultimately avoid the provider being blamed for clinical inertia from untreated diseases versus the disease progress expected especially in clusters 1 and 2. As clusters 1 and 2 require the most aggressive pharmacological management.

In short, there has been much discourse within the literature concerning Ahlqvist et al. [1] findings of five separate new classifications of type 2 diabetes [3,9]. Both B Ahlqvist et al. [1] and Koivula et al. [10] indicate the current characterizations of type 2 diabetes may well be improved via further research, use of specific biomarkers, genotypes and genetic risk scores. These investigators also maintain that since C-peptide levels remained stable within the clusters of newly diagnosed and those living with long term diabetes this indicated discrete subtypes versus different stages of the disease [1]. Thus, the stratification of diabetes related sub-types based on clinical and route makers has merit. In order, to fully tailor diabetes management by subtypes perhaps C-peptide and GADA levels will need to become more available in primary care. As well as for providers to calculations of HOMA2. This research brings forth an opportunity to begin the precision targeting of care for patients living with type 2 diabetes.

\section{References}

1. Ahlqvist E, Storm P, Käräjämäki A, Martinell M, Dorkhan M, et al. (2018) Novel subgroups of adult-onset diabetes and their association with

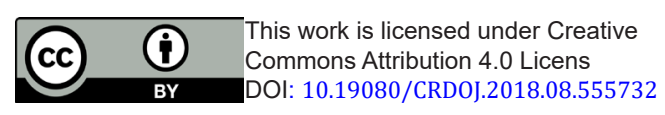

outcomes: a data-driven cluster analysis of six variables. The Lancet Diabetes \& Endocrinology 6(5): 361-369.

2. Gloyn AL, Drucker DJ (2018) Precision medicine in the management of type 2 diabetes. The Lancet Diabetes \& Endocrinology.

3. Ahlqvist E, Prasad RB, Tuomi T, Rosengren A, Groop L (2018) Novel diabetes subgroups-authors' reply. Lancet Diabetes Endocrinol 6(6): 440-441.

4. Appel SJ, Wadas TM, Rosenthal RS, Ovalle F (2009) Latent autoimmune diabetes of adulthood (LADA): an often misdiagnosed type of diabetes mellitus. J Am Acad Nurse Pract 21(3): 156-159.

5. Li X, Yang L, Zhou Z, Huang G, Yan X (2003) Glutamic acid decarboxylase 65 autoantibody levels discriminate two subtypes of latent autoimmune diabetes in adults. Chin Med J (Engl) 116(11): 1728-1732.

6. Prasad RB, Groop L (2015) Genetics of type 2 diabetes-pitfalls and possibilities. Genes 6(1): 87-123.

7. Caumo A, Perseghin G, Brunani A, Luzi L (2006) New insights on the simultaneous assessment of insulin sensitivity and $\beta$-cell function with the HOMA2 method. Diabetes Care 29(12): 2733-2734.

8. Van Cauter E, Mestrez F, Sturis J, Polonsky KS (1992) Estimation of insulin secretion rates from C-peptide levels: comparison of individual and standard kinetic parameters for C-peptide clearance. Diabetes 41(3): 368-377.

9. Cengizhan MS, Celik M (2018) New subgroups classified in adult diabetes mellitus. Archives of Diabetes and Endocrine System 1(1): $1-2$.

10. Koivula RW, Forgie IM, Kurbasic A, Viñuela A, Heggie A, et al. (2018) Discovery of biomarkers for glycaemic deterioration before and after the onset of type 2 diabetes: an overview of the data from the epidemiological studies within the IMI DIRECT Consortium. Diabetologia 57(6): 1132-1142.

\begin{tabular}{l} 
Your next submission with Juniper Publishers \\
will reach you the below assets \\
- Quality Editorial service \\
- Swift Peer Review \\
- Reprints availability \\
- E-prints Service \\
- Manuscript Podcast for convenient understanding \\
- Global attainment for your research \\
- Manuscript accessibility in different formats \\
( Pdf, E-pub, Full Text, Audio) \\
- Unceasing customer service \\
Track the below URL for one-step submission \\
https://juniperpublishers.com/online-submission.php \\
\hline
\end{tabular}

